\title{
Diverse Members of the AvrBs3/PthA Family of Type III Effectors Are Major Virulence Determinants in Bacterial Blight Disease of Rice
}

\author{
Bing Yang and Frank F. White \\ Department of Plant Pathology, Kansas State University, Manhattan, KS 66502, U.S.A.
}

Submitted 11 May 2004. Accepted 28 June 2004.

\begin{abstract}
AvrXa7 is a member of the avBs3/pthA gene family and the only known type III secretion system effector gene from Xanthomonas oryzae pv. oryzae with a major contribution to bacterial growth and lesion formation in bacterial blight disease of rice. We examined the general requirement for effectors of the AvrBs3/PthA family in bacterial blight of rice by identifying effectors from diverse strains of the pathogen. Inactivation of single effector genes in representative strains from Japan, Korea, and the Philippines resulted in severely limited growth in plants. Five strains harbored one gene of the avrBs3/pthA family, while one strain had two genes with the equivalent virulence activity of $a v r X a 7$. Sequence analysis revealed three genes with unique repeat arrangements in comparison to avrXa7. Comparison of the repetitive regions revealed a potential motif for the group that was also present in the repetitive region of avrBs3. However, the repetitive region of avrBs3 could not support virulence activity but, in combination with the $\mathrm{C}$-terminal coding region of avrXa7, triggered a $\mathrm{Xa} 7$-dependent avirulence reaction. The results revealed diverse members of the avrBs3/pthA gene family with virulence activity in $X$. oryzae pv. oryzae and supported the hypothesis that bacterial blight disease of rice is highly dependent on a single class of type III effectors. The results also indicated that $a v r X a 7$ avirulence specificity is separable from virulence activity.
\end{abstract}

Many gram-negative pathogenic bacteria are highly dependent on the type III secretion systems (TTSS) for virulence (Staskawicz et al. 2001). The TTSS pathways mediate the secretion of proteins (substrate virulence effectors) into the extracellular milieu and into the host cells themselves, wherein the effectors facilitate virulence (Buttner et al. 2002). Ablation of the TTSS in plant pathogen systems often results in the loss of pathogenesis or severe reduction of virulence. Substrate effectors of individual strains, on the other hand, are highly variable (Deng et al. 2003; Guttman et al. 2002; Salanoubat et al. 2002). Loss of individual effector genes often results in modest or no observable effects on virulence (White et al. 2000). The apparent modest role of individual effectors may be attributable to multiple factors, including effector redundancy, the incremental requirements for multiple effectors, or inappropriate testing environment. Nevertheless, type III effectors have a critical function in the ecology of the disease-causing species.

Corresponding author: F. White: E-mail: fwhite@ksu.edu

* The $\boldsymbol{e}$-Xtra logo stands for "electronic extra" and indicates that Figures 4 and 9, which are black and white in the print edition, appear in color on-line.
AvrBs2 was the first identified bacterial TTSS effector with virulence and avirulence activities and remains an important example of TTSS effector function (Kearney and Staskawicz 1990). The protein has avirulence activity when the strain harboring the gene for AvrBs2 is inoculated on pepper plants containing the $B s 2$ gene for resistance. Loss of avrBs 2 in Xanthomonas campestris pv. vesicatoria results in an approximate fivefold loss in bacterial growth in the pepper plants (Gassmann et al. 2000). Genes for AvrBs2 homologs are present in many species and pathovars of Xanthomonas, suggesting that AvrBs2 has an important function in the general physiology of the various pathogens. A variety of type III effector genes have since been shown associated with virulence in plant pathogenic bacteria (Chang et al. 2004).

A few individual effector genes have dramatic effects on the virulence of the strains of phytopathogenic bacteria that harbor them. Principle among these are pthA (pathogenicity $A$ ) of Xanthomonas axonopodis pv. citri and avrXa7 of X. oryzae pv. oryzae, both of which are required for full virulence of the respective strains on their host plants (Bai et al. 2000; Swarup et al. 1991; Yang et al. 2000). Loss of either $p t h A$ or $a v r X a 7$ from their respective strains resulted in severe reductions in symptoms and the ability of the pathogen to multiply within the host tissue. Related genes in $X$. campestris pv. malvacearum have been shown to have a cumulative yet similar impact in strain $\mathrm{XcmH1005,} \mathrm{where} \mathrm{sequential} \mathrm{elimination} \mathrm{of} \mathrm{multiple} \mathrm{copies}$ of avrBs3/pthA genes was required before significant loss of virulence occurs (Yang et al. 1996). Additional copies of the family in $X$. oryzae pv. oryzae are also known to have additional yet minor contributions to virulence in strain PXO86, the original source of $a v r X a 7$ (Bai et al. 2000).

PthA, avrb6, and $a v r X a 7$ are members of the avrBs3/pthA gene family, the members of which are found in many Xanthomonas species and, recently, within the genome of Ralstonia solanacearum GMI1000 (Bonas et al. 1989; Salanoubat et al. 2002). Members of the avrBs3/pthA family are remarkably similar, differing primarily in the number and apparent nature of near-identical 102-base-pair direct repeats in the central portion of the coding sequence, which is referred to here as the repetitive region (White et al. 2000). The repetitive regions contribute to function and specificity during the elicitation of resistance and, in the absence of resistance, virulence on the respective host species (Herbers et al. 1992; Yang et al. 1994).

$X$. oryzae pv. oryzae is the causal organism of bacterial blight of rice. Evidence from field studies on strains with $\mathrm{Xa7}$ dependent avirulence activity indicated that the predominant strains also have a dependency on $a v r X a 7$ for virulence (Vera Cruz et al. 2000). At the same time, many strains of $X$. oryzae 
pv. oryzae have no $X a 7$-mediated avirulence activity, and the prevalence of related virulence effectors within $X$. oryzae pv. oryzae populations is unknown. Strains without $\mathrm{Xa} 7$-dependent avirulence activity may suppress the activity due to $a v r X a 7$, have another virulence gene of the same family without $X a 7$-mediated avirulence activity, or rely on unrelated effectors. We, therefore, examined the prevalence of $a v r X a 7$ and related genes in the ability of diverse strains of $X$. oryzae pv. oryzae to cause disease. X. oryzae pv. oryzicola, which is a closely related pathogen and causes a nonvascular disease of rice called bacterial leaf streak, could possibly exchange effector genes with $X$. oryzae pv. oryzae in nature and represents a potential source of virulence effector genes. Therefore, an attempt was also made to identify virulence effectors from strain BLS303 of $X$. oryzae pv. oryzicola by complementation of a low virulence mutant of $X$. oryzae pv. oryzae.

\section{RESULTS}

Homologs of $a v r X a 7$ are critical virulence factors in diverse strains of $X$. oryzae pv. oryzae.

Two approaches were taken to determine whether strains of $X$. oryzae pv. oryzae possessed additional virulence effectors

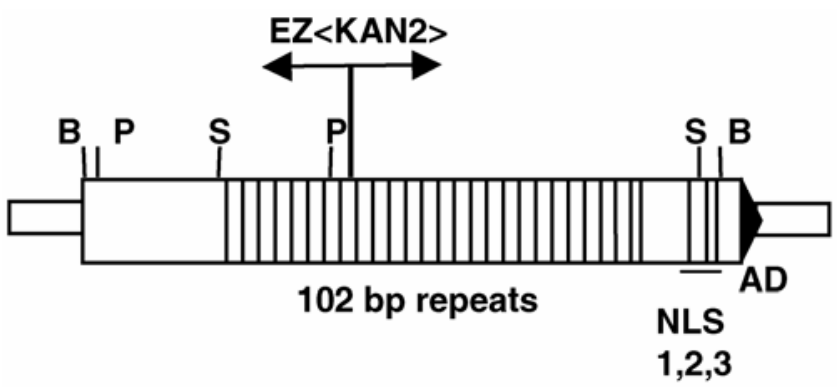

Fig. 1. Map of $a v r X a 7$. The gene is $4,341 \mathrm{bp}$ in length. Functional regions indicated are the three nuclear localization signal motifs (NLS1, 2, 3) and an acidic activation domain (AD) in the $\mathrm{C}$-terminal coding region. The EZ< KAN2> insertion used in mutagenesis is indicated above repetitive region. Code for restriction enzyme cleavage sites: $\mathrm{B}=$ BamHI; $\mathrm{P}=$ Pst $\mathrm{I} ; \mathrm{S}=\operatorname{Sph} \mathrm{I}$. of the AvrBs3/PthA family. The first approach generated mutations in avrBs3/pthA-related genes in selected strains by homologous recombination or so-called knock-out mutagenesis, using a mutant copy of the $a v r X a 7$ (Fig. 1). If a strain was dependent on a single effector of the gene family, then some kanamycin-resistant strains would suffer an appreciable loss of virulence. The lack of low virulence recombinants could be due to multiple yet equally competent virulence effector genes, multiple effector genes that contribute incrementally to virulence, or simply the lack of major effector genes of the avrBs3/pthA type in a particular strain. The mutant strains were examined by Southern hybridization to assess the number of rearrangements among the gene family members and to determine the number of recombination events associated with the antibiotic resistance marker.

A variety of strains were selected on the basis of lineage and diverse geographic origin and included $\mathrm{JXO1}^{\mathrm{A}}$, PXO61, PXO71, PXO99 ${ }^{\mathrm{A}}$, and KXO85 ${ }^{\mathrm{A}}$ (Table 1). The target strains were analyzed for avrBs3/avrPthA gene content by Southern hybridization prior to genetic analyses. Genomic DNA was digested with SphI, which cleaves on either side of the repeat coding region of most avrBs3/pthA genes, including avrXa7, and was probed with the central SphI fragment of avrXa7. Hybridization signal revealed multiple fragments in each genome (Fig. 2). The observed bands are presumed to represent the internal SphI fragments of gene family members in each genome, which differ in size according to the number of repeat units, although some bands may represent truncated genes within each strain. Assuming each band represented an intact gene, each strain of $X$. oryzae pv. oryzae was estimated to harbor approximately 14 to 16 copies. The copy number of genes in X. oryzae pv. oryzicola BLS303 was estimated at 18 copies. Thus, all of the strains could potentially carry one or more closely related copies of a virulence effector gene of the avrBs3/pthA family.

Mutagenesis was performed on the selected strains (with the exception of BLS303) by introducing the central $4.2-\mathrm{kb}$ Bam HI fragment of $a v r X a 7$ containing a gene for resistance to kanamycin in the eighth repeat (Fig. 1; discussed below). Isolates of PXO99 ${ }^{\mathrm{A}}, \mathrm{JXO}^{\mathrm{A}}$, and $\mathrm{KXO}^{\mathrm{A}}(30,6$, and 10 respectively) were selected as resistant to kanamycin after transfor-

Table 1. Bacterial strains and plasmids used in this study

\begin{tabular}{|c|c|c|}
\hline Designation & Genotypes or relevant characteristics & Source or reference \\
\hline \multicolumn{3}{|l|}{ Plasmids } \\
\hline pUC19 & Resistance to carbenicillin $\left(\mathrm{Cb}^{\mathrm{r}}\right)$ & Yanisch-Perron et al. 1985 \\
\hline pHM1 & Broad host range resistance to spectinomycin, polylinker, $\cos$ site & Hopkins et al. 1992 \\
\hline pZWavrXa7 & avrXa7 in pBluescript II $\mathrm{KS}+$, unique HindIII site after avrXa7 coding region & Yang et al. 2000 \\
\hline pBY1 & 4.1-kb BamHI fragment of $a v r X a 7$ in pUC19, EZ:TN [Kan-2] in 8th repeat of $a v r X a 7$ & This study \\
\hline pZWpthXo1 & SphI fragment of pthXo1 in pZWavrXa7 & This study \\
\hline pZWpthXo2 & SphI fragment of pthXo2 in pZWavrXa7 & This study \\
\hline pZWpthXo3 & SphI fragment of pthXo3 in pZWavrXa7 & This study \\
\hline pZWavrBs3-7HS & HincII/SalI fragment of avrXa7 in pZWavrBs3 & This study \\
\hline \multicolumn{3}{|l|}{ Escherichia coli } \\
\hline DH5 $\alpha$ & F' recA, $\phi 80$ dlacZ, $\triangle M 15$ & Stratagene, La Jolla, CA, U.S.A. \\
\hline XL1-Blue MRF' & F'proAB lacI ${ }^{\mathrm{q}} \mathrm{Z} \Delta M 15 \operatorname{Tn} 10\left(\mathrm{Tet}^{\mathrm{r}}\right)$ & Stratagene \\
\hline $\mathrm{C} 2110$ & $\mathrm{Nal}^{\mathrm{r}} \operatorname{Rif}^{\mathrm{r}}($ polA1, rha, his) & Leong et al. 1982 \\
\hline \multicolumn{3}{|c|}{ Xanthomonas oryzae pv. oryzae } \\
\hline PXO99A & Philippine race 6; azacytidine resistant clone of PXO99 & Hopkins et al. 1992 \\
\hline $\mathrm{JXO1}^{\mathrm{A}}$ & Japanese race 1 & J. Leach, Kansas State University \\
\hline $\mathrm{KXO} 85^{\mathrm{A}}$ & Korean strain CK89021 (KAXCC10331) & J. Leach \\
\hline PXO61 & Philippine race 1 & J. Leach \\
\hline PXO71 & Philippine race 4 & J. Leach \\
\hline PXO86 & Philippine race 2 , original source of $a v r X a 7$ & Hopkins et al. 1992 \\
\hline PXO999 ME2 & PXO99 with pBY1 inserted into $p$ thXol & This study \\
\hline JXO1 ${ }^{\mathrm{A}} \mathrm{ME5}$ & JXO1A with pBY1 inserted into pthXo2 & This study \\
\hline $\mathrm{KXO} 85^{\mathrm{A}} \mathrm{ME} 3$ & PXO99 with pBY1 inserted into $a v r X a 7-2$ & This study \\
\hline \multicolumn{3}{|c|}{$X$. oryzae pv. oryzicola } \\
\hline BLS303 & Philippines, bacterial leaf streak pathogen of rice & J. Leach \\
\hline
\end{tabular}


mation. Although mutagenesis of PXO61 and PXO71 was attempted, no kanamycin-resistant colonies were obtained, suggesting that restriction/modification systems may be preventing efficient DNA transfer in these two strains. No further

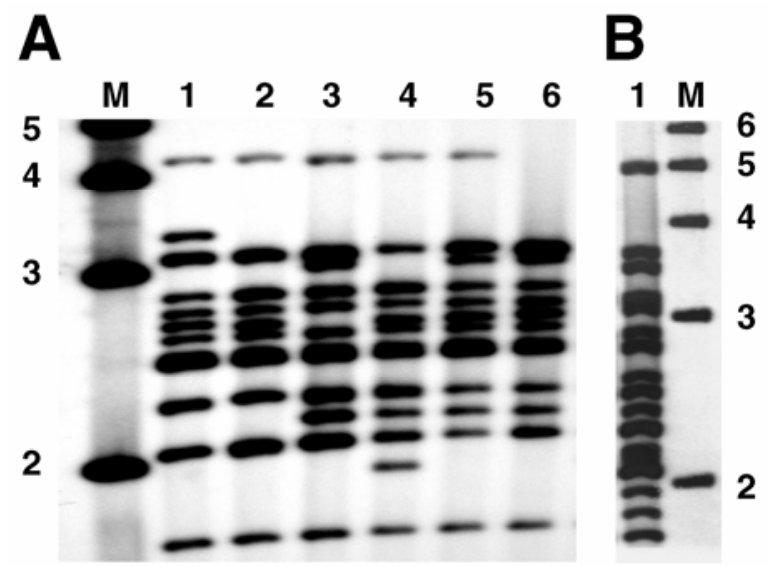

Fig. 2. Southern analysis of avrBs3/pthA genes in strains and pathovars of Xanthommonas oryzae pv. oryzae. DNA from strains was digested with $S p h \mathrm{I}$ and was probed with the 3.1-kb SphI fragment of avrXa7. M represents molecular size markers. A, Lane 1, PXO61; lane 2, PXO71; lane 3, PXO86; lane 4, PXO99 ${ }^{\mathrm{A}}$; lane 5, JXO1 ${ }^{\mathrm{A}}$; lane $6, \mathrm{KXO}^{\mathrm{A}}$. B, Lane 1, X. oryzae pv. oryzicola BLS303. Numbers at each side indicate size of standards in $\mathrm{kb}$. attempts were made to generate mutants in PXO61 and PXO71. Five recombinant isolates of $\mathrm{PXO} 99^{\mathrm{A}}$ displayed reduced virulence, while one and two reduced-virulence mutants were identified from $\mathrm{JXO}^{\mathrm{A}}$ and $\mathrm{KXO} 85^{\mathrm{A}}$, respectively.

The genomic DNA from recombinants was analyzed by Southern hybridization using the $S p h \mathrm{I}$ fragment of $a v r X a 7$ and, separately, antibiotic resistance gene of the transposon element as probes. The results for PXO99 ${ }^{\mathrm{A}}$ are shown as an example of the analyses. PXO99 ${ }^{\mathrm{A}}$ recombinants had a variety of polymorphisms associated with the avrBs3/pthA gene family (Fig. 3A). Low virulence in PXO99 ${ }^{\mathrm{A}}$ recombinants was associated with the change of a doublet band to a singlet band of approximately $2.9 \mathrm{~kb}$ (Fig. 3A). Additional and multiple polymorphisms were detected in some strains. For example, PXO99 ${ }^{\mathrm{A} M E 2}$ and PXO99 ${ }^{\mathrm{A}}$ ME42 both suffered the loss of a 1.9-kb fragment. However, PXO99 ${ }^{\mathrm{A}} \mathrm{ME} 42$ was fully virulent and possessed the doublet band at $2.9 \mathrm{~kb}$ (Fig. 3A). Upon probing with the fragment from the recombination marker, most strains were found to have a single band indicative of a single transposon (data not shown). The marker was associated with a 3.6-kb polymorphic fragment in PXO99 ${ }^{\mathrm{A}} \mathrm{ME} 2$ (Fig. 3A, marked by an asterisk).

Recombinants from $\mathrm{JXO} 1^{\mathrm{A}}$ and $\mathrm{KXO} 85^{\mathrm{A}}$ were similarly analyzed, and in each case, a common fragment was identified in reduced virulence strains (data not shown). Representative recombinants (PXO99 ${ }^{\mathrm{A}} \mathrm{ME} 2, \mathrm{JXO} 1^{\mathrm{A}} \mathrm{ME} 5$, and $\mathrm{KXO} 85^{\mathrm{A}} \mathrm{ME} 3$ ) with a single transposon, as evidenced by hybridization analysis

A

B

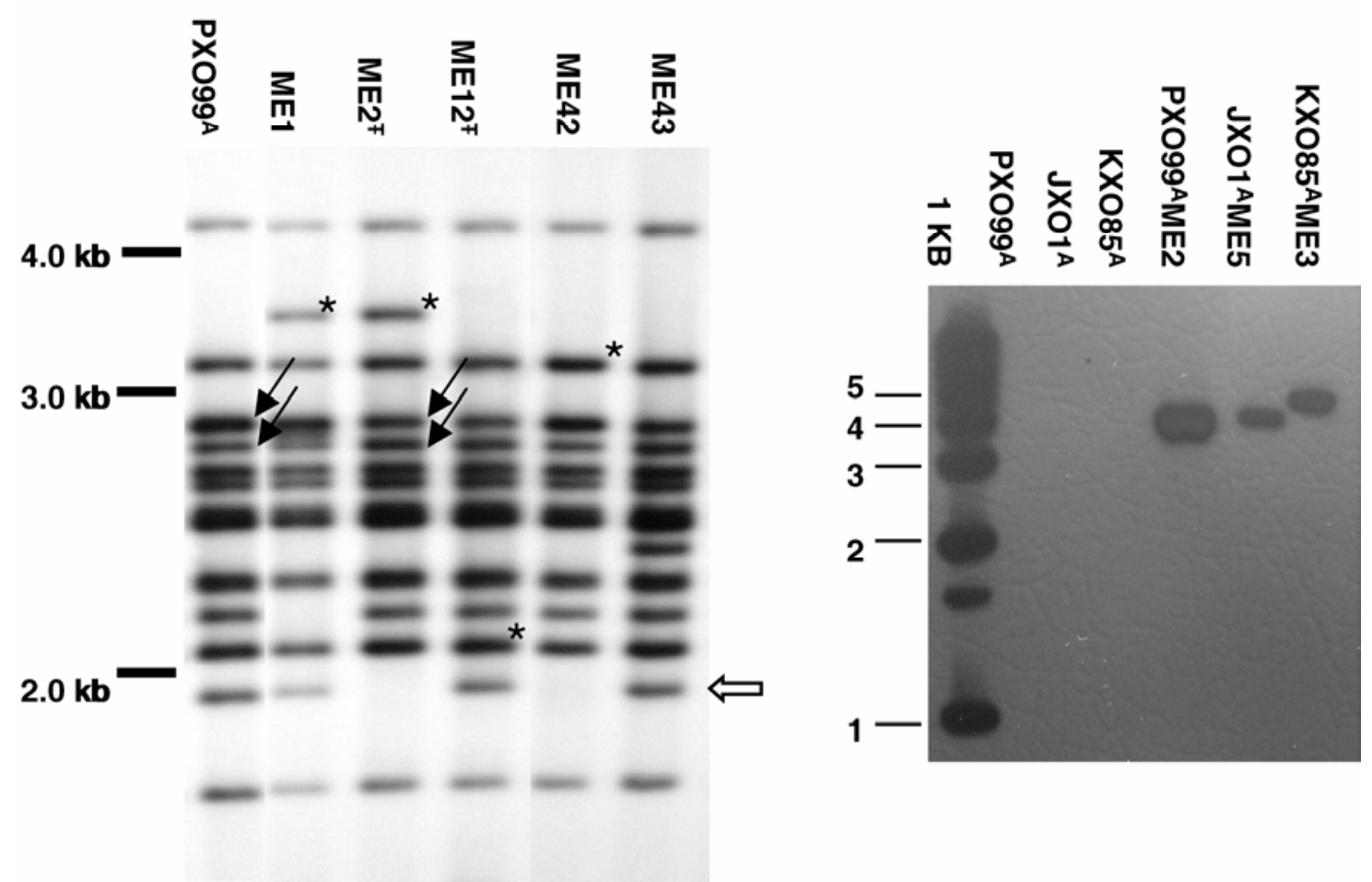

Fig. 3. A, Southern hybridization analysis of genomic DNA from kanamycin-resistant isolates of PXO99A. DNA was digested with SphI and was probed with the SphI fragment of avrXa7. The positions of the size markers are indicated at left. Strain names are indicated at top. Strain names followed with " $F$ " designate strains with low virulence (ME2 and ME12). The solid arrows indicate band in ME2 of lower intensity relative to wild type and common to lowvirulence strains and the band immediately below the $2.9-\mathrm{kb}$ band, which does not change in intensity relative to wild type. The open arrow at right indicates an example of polymorphism not associated with low-virulence phenotype. Asterisks indicate bands associated with antibiotic resistance gene, which was used as a recombination marker. B, Southern hybridization analysis of genomic DNA from low-virulence strains PXO99 ${ }^{\mathrm{A}}$ ME2, JOX1 ${ }^{\mathrm{A}}$ ME5, and KXO85 ${ }^{\mathrm{A}} \mathrm{ME3}$. Genomic DNA from each strain was digested with $S p h \mathrm{I}$ and was probed with a polymerase chain reaction fragment of the recombination marker. Strain names are indicated at the top. Size marker bands are indicated at left and were detected by spiking the probe with labeled 1-kb ladder DNA. Arrows at right indicate individual bands from each mutant. The density differences betwween PXO99 ${ }^{\mathrm{A}} \mathrm{ME} 2$, JXO1 ${ }^{\mathrm{A}} \mathrm{ME} 5$, and KXO85 ${ }^{\mathrm{A}} \mathrm{ME} 3$ are due to uneven DNA loading of genomic DNA. 
(Fig. 3B) and reduced virulence, were selected for study. Inoculation of parental strains $\mathrm{PXO} 99^{\mathrm{A}}$, $\mathrm{JXO}^{\mathrm{A}}$, and $\mathrm{KXO}^{\mathrm{A}} 5^{\mathrm{A}}$ into 14day-old rice leaves resulted in typical water-soaked symptoms within the inoculated area within 3 days (Fig. 4, leaves 1, 3, and 5 , respectively). The water-soaked tissue, which has a glassy or wet appearance, appeared as dark area within the background of the lighter uninfected leaf tissue. PXO99 ${ }^{\mathrm{A}} \mathrm{ME}$, JXO1 ${ }^{\mathrm{A}} \mathrm{ME}$, and $\mathrm{KXO} 85^{\mathrm{A}} \mathrm{ME} 3$ each caused symptoms with reduced watersoaked symptoms at the inoculation site (Fig. 4, leaves 2, 4, and 6 , respectively). $\mathrm{KXO} 85^{\mathrm{A}}$ is the only strain of the study with $\mathrm{X} a 7$-dependent avirulence activity. $\mathrm{KXO} 85^{\mathrm{A}}$ was isolated in South Korea and represented a different lineage than PXO86, the original source of $a v r X a 7 . \mathrm{KXO} 85^{\mathrm{A}} \mathrm{ME} 3$ concomitantly lost the ability to elicit a $X a 7$-dependent hypersensitive response, indicating that a dual active homolog to $a v r X a 7$ was present in the strain (data not shown).

Although bacterial numbers were not measured for all mutants, bacterial numbers were previously shown to be strictly correlated to lesion length (Bai et al. 2000; Yang et al. 2000). Bacterial populations were measured for the PXO99 ${ }^{\mathrm{A}}$ and PXO99 ${ }^{\mathrm{A}}$ ME2. The populations for PXO99 ${ }^{\mathrm{A}}$ and PXO99 ${ }^{\mathrm{A}} \mathrm{ME2}$ at day 10 , the final day of lesion-length measurements, were $6.1 \times 10^{8} \pm 0.7$ and $9.5 \times 10^{6} \pm 0.3 \mathrm{CFU}$ per leaf.

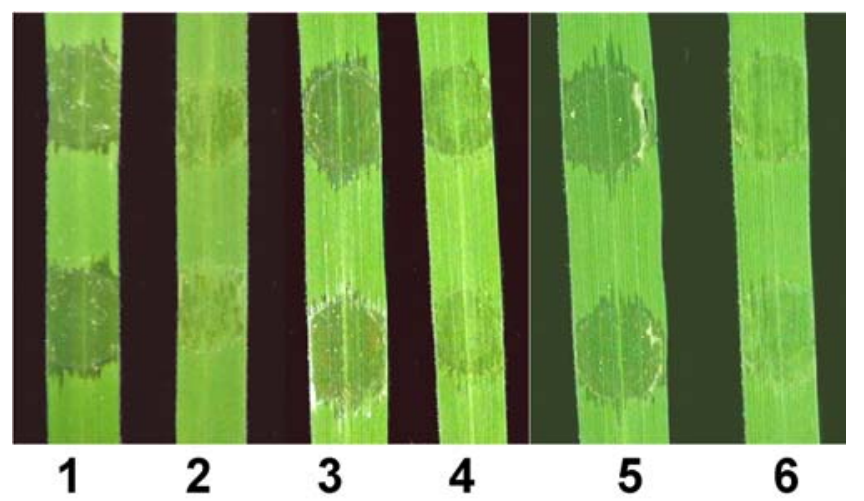

Fig. 4. Phenotype of virulence mutants of Xanthomonas oryzae pv. oryzae on rice leaves. Each strain was inoculated by needleless syringe on 14day-old seedlings of cultivar IR24. Leaves were photographed four days after inoculation. Leaf 1, PXO99 ${ }^{\mathrm{A}}$; leaf 2, PXO99 ${ }^{\mathrm{A}} \mathrm{ME2}$; leaf 3, $\mathrm{JXO}^{\mathrm{A}}$; leaf 4, JXO1 ${ }^{\mathrm{A} M E 5}$; leaf 5, KXO85 ${ }^{\mathrm{A}}$; and leaf 6, KXO85 ${ }^{\mathrm{A}} \mathrm{ME} 3$.

\section{Reduced virulence mutants were complemented by single virulence effector genes \\ from the avrBs3/pthA family.}

The hybridization data indicated PXO99 ${ }^{\mathrm{A}} \mathrm{ME} 2, \mathrm{JXO} 1^{\mathrm{A}} \mathrm{ME}$, and $\mathrm{KXO} 85^{\mathrm{A}} \mathrm{ME} 3$ had each suffered the loss of a single gene of the avrBs3/pthA gene family with virulence activity. Complementation tests were used to identify the respective effector gene from PXO99 ${ }^{\mathrm{A}}, \mathrm{JXO1}^{\mathrm{A}}$, and $\mathrm{KXO}{ }^{\mathrm{A}}$ from cosmid libraries of the $a v r X a 7$-related genes from each strain in the broad-hostrange vector $\mathrm{pHM}$. Each library was transferred initially to PXO99 ${ }^{\mathrm{A}} \mathrm{ME} 2$, which is the best recipient for transfer of clones with large inserts, and the cosmids with candidate effector genes were identified by syringe-inoculation of the transformants (Table 2). Syringe-inoculation, while not quantitative, was used for rapid screening of candidate genes during cosmid screening and subcloning. Single cosmids often contained two or three avrBs3/pthA genes. After identification of cosmid clones harboring complementing genes, Bam HI fragments containing single candidate genes were identified by hybridization analyses and were subcloned. Each candidate gene was partially sequenced, using primers from sequences immediately upstream and downstream from the repetitive region (discussed below). The partial sequencing analysis revealed five to six repeats from each end of the repetitive region and allowed distinguishing of potentially different genes of the same size. One candidate effector gene was identified from $\mathrm{PXO} 99^{\mathrm{A}}, \mathrm{JXO}^{\mathrm{A}}$, and $\mathrm{KXO} 85^{\mathrm{A}}$. The genes from PXO99 ${ }^{\mathrm{A}}$ and $\mathrm{JXO} 1^{\mathrm{A}}$ were named pthXol and pthXo2, respectively (Table 2). The gene from $\mathrm{KXO}^{\mathrm{A}}$ also conferred $X a 7$-dependent avirulence activity and was named $a v r X a 7-2$.

Table 2. Cosmid clones of avrBs3/pthA gene family members

\begin{tabular}{|c|c|c|c|}
\hline \multirow[b]{2}{*}{$\begin{array}{l}\text { Strain } \\
\text { library }\end{array}$} & \multicolumn{2}{|c|}{ Cosmids } & \multirow[b]{2}{*}{$\begin{array}{c}\text { Identified } \\
\text { virulence gene }\end{array}$} \\
\hline & 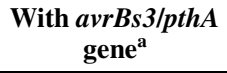 & $\begin{array}{l}\text { With virulence } \\
\text { activity }\end{array}$ & \\
\hline PXO99А & 28 & 3 & pthXo1 \\
\hline $\mathrm{JXO}^{\mathrm{A}}$ & 32 & 4 & pthXo2 \\
\hline $\mathrm{KXO} 85^{\mathrm{A}}$ & 25 & 3 & avrXa7-2 \\
\hline PXO61 & 26 & 3 & pthXo3 \\
\hline PXO71 & 27 & 4 & $\begin{array}{l}\text { pthXo1-2, } \\
\text { pthXo2-2 }\end{array}$ \\
\hline BLS303 & 35 & 0 & none \\
\hline
\end{tabular}

${ }^{a}$ Cosmids were selected by hybridization to avrXa7 probe and often contained multiple genes of the same gene family.
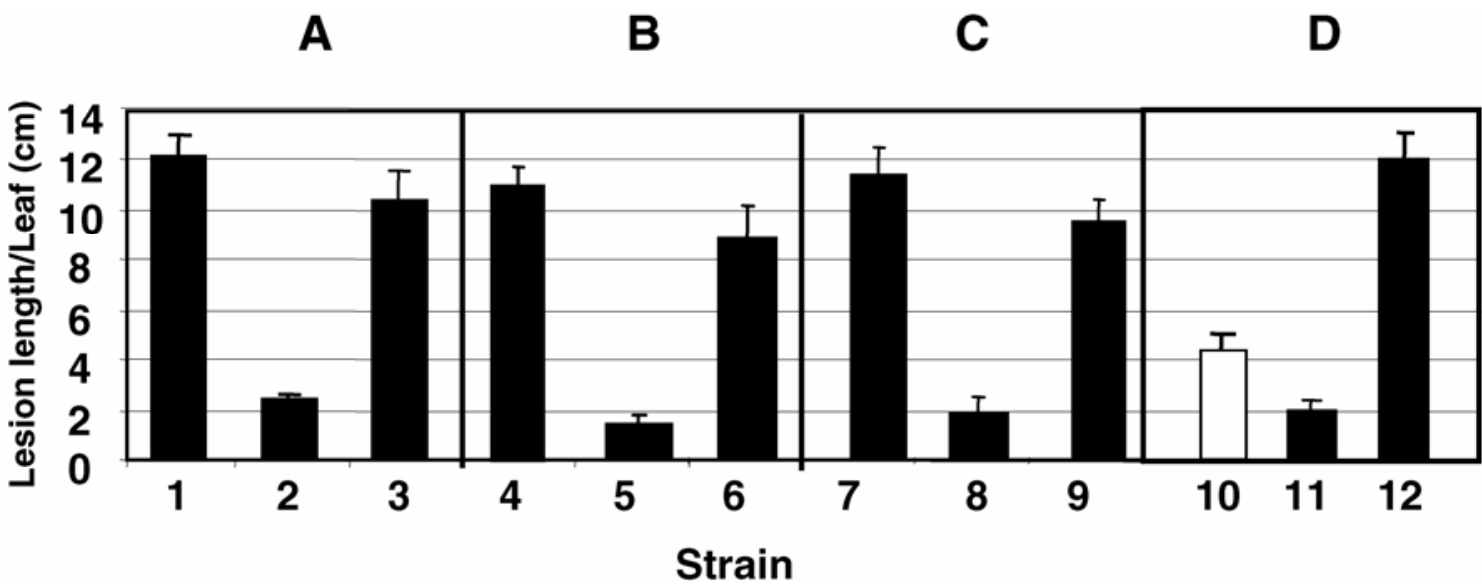

Fig. 5. Complementation analyses of low virulence mutants of Xanthomonas oryzae pv. oryzae. The virulence effector gene from each parental strain was introduced into the respective mutant, and $\mathbf{A}$, through $\mathbf{C}$, the resulting transformants were tested for virulence using the leaf-clip inoculation method on rice cultivar IR24. D, IRBB7 (Xa7) leaves were leaf-clip inoculated by PXO86 (containing avrXa7), PXO99 ${ }^{\mathrm{A}}$, and PXO99 $\mathrm{AE2}$ for comparison of incompatible and compatible reactions. Strains were as follows. Column 1, PXO99 ${ }^{\mathrm{A}}$; 2, PXO99 ${ }^{\mathrm{A}}$ ME2; 3, PXO99 ${ }^{\mathrm{A}}$ ME2 (pZWpthXo1); 4, JXO1 ${ }^{\mathrm{A}}$; 5, JXO1 ${ }^{\mathrm{A}}$ ME5; 6, JXO1 ${ }^{\mathrm{A}}$ ME5 (pZWpthXo2); 7, KXO85 ${ }^{\mathrm{A}}$; 8, KXO85 ${ }^{\mathrm{A}} \mathrm{ME3}$; and 9, KXO85 ${ }^{\mathrm{A}} \mathrm{ME} 3$ (pZWavrXa7-2); 10, PXO86; 11, PXO99 ${ }^{\mathrm{A}}$ ME2; and 12, PXO99 ${ }^{\mathrm{A}}$. Lesion lengths were measured 10 days after inoculation of 20-day-old seedlings. 
The candidate genes were next tested for complementation of the respective low-virulence mutant of the parental strain. Upon transfer of the virulence effector gene to the respective mutant, each strain recovered in virulence, as indicated by lesion-length assays (Fig. 5). The plasmid copy of each respective virulence effector gene did not fully restore virulence to that of the parental strain, as measured by lesion length. $\mathrm{PXO}^{\mathrm{A}}$ is the most virulent strain, based on lesion length assays, and reintroduction of $p t h X o 1$ restored virulence to $86 \%$ of the parental strain. Similarly, pthXo2 and $a v r X a 7-2$ restored virulence to 78 and $83 \%$ of their respective parental strains. The lack of full complementation was also observed in previous studies with $a v r X a 7$, which restored virulence to PXO86mx53 to $86 \%$ of the parental strain PXO86 (Bai et al. 2000; Yang et al. 2000), and the reasons are unknown.

The reduction in lesion length by $\mathrm{PXO} 99^{\mathrm{A}} \mathrm{ME} 2$ due to the loss of pthXol was also compared with reduction in lesion length due to the resistance reaction in the $a v r X a 7 / X a 7$ gene combination in strain PXO86 on the rice line IRBB7 (Fig. 5D, column 10). The lesion lengths due to inoculation with PXO99 ${ }^{\mathrm{A}}$ ME2 were shorter than lesion length due to the elicitation of resistance (Fig. 5D, column 11).

\section{The virulence effectors}

of the AvrBs3/PthA family are interchangeable.

The ability of the different genes to contribute to the virulence of a single strain was tested by cross complementation

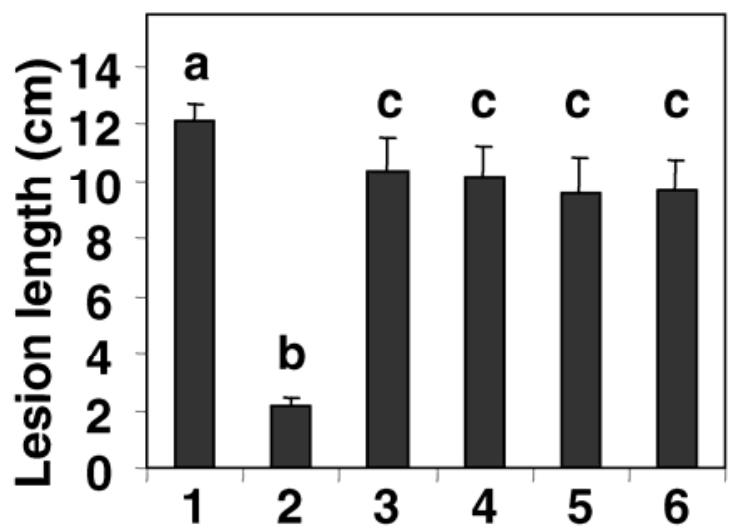

Fig. 6. Virulence complementation by different $p$ th genes in PXO99 ${ }^{\mathrm{A}} \mathrm{ME} 2$. Lesion lengths were measured 10 days after inoculation of IR24 with PXO99 $^{\mathrm{A}}$ (column 1) and PXO99 ${ }^{\mathrm{A}} \mathrm{ME} 2$ containing pHM1 (column 2), pthXo1 (column 3), pthXo2 (column 4), pthXo3 (column 5), and avrXa7 (column 6). Lesion length is indicated at left. Columns with the same letter indicate no significant differences at $P<0.05$ by post-analysis of variance pairwise comparisons with the Tukey honestly significant difference test. of the loss of pthXol in PXO99 ${ }^{\mathrm{A}} \mathrm{ME2}$. Prior to cross-complementation analyses, an attempt was made to identify additional related effector genes from libraries of PXO61 and PXO71, in which no reduced-virulence mutants were obtained, and one strain of X. oryzae pv. oryzicola, BLS303. A single candidate gene was identified in PXO61 and two candidate genes were recovered from PXO71 by cross complementation of virulence in PXO99 ${ }^{\mathrm{A}} \mathrm{ME} 2$ (Table 2). No complementing clones were identified in a library of avrBs $3 / p t h A$ homologs from BLS303. Two distinct clones from PXO71 were identified that complemented PXO99 ${ }^{\mathrm{A}} \mathrm{ME} 2$. However, initial sequencing of the $S p h \mathrm{I}$ fragments, size similarity, and subsequent sequencing analysis led to the conclusion that the genes from PXO71 were similar to the genes from PXO99 ${ }^{\mathrm{A}}$ and $\mathrm{JXO} 1^{\mathrm{A}}$, respectively, and were named pthXol-2 and pthXo2-2. A single unique gene was identified in PXO61 and was named $p t h X o 3$.

The three distinct virulence effectors ( $a v r X a 7, p t h X o 2$, and pthXo3) were transferred individually to PXO99 ${ }^{\mathrm{A}} \mathrm{ME} 2$, and their effects were compared with complementation with pthXol. Each transformant was tested on IR24 leaves for virulence by using syringe- and clip-inoculation methods. All transformants caused strong water-soaking symptoms like wild-type strain PXO99A (data not shown). Lesion length measurements indicated that each gene complemented the loss of pthXol from PXO99 ${ }^{\mathrm{A}} \mathrm{ME} 2$ to an equal degree (Fig. 6).

\section{Virulence effectors of the AvrBs3/PthA family \\ in $X$. oryzae pv. oryzae have diverse repetitive regions.}

The central SphI fragment of each complementing gene was sequenced, revealing that $p t h X o 1$ from $\mathrm{PXO} 99^{\mathrm{A}}, p t h X o 2$ from $\mathrm{JXO} 1^{\mathrm{A}}$, and $p t h X o 3$ from PXO61 were novel genes in terms of the number and arrangement of the predicted repeats in their respective repetitive regions, when compared with $a v r X a 7$ and other family members (Fig. 7). The two genes from PXO71 were nearly identical to pthXol and pthXo2, respectively, at the nucleotide level, and the gene from $\mathrm{KXO}^{\mathrm{A}}$ was nearly identical to $a v r X a 7$ (data not shown). pthXol had 23.5 repeat units compared with the 25.5 repeats of avrXa7. pthXo2 had 21.5 repeats, and pthXo3 had 28.5 repeats. Although each gene was distinct, $a v r X a 7$ and pthXo3 have the most similar features. Each contained an 18bp duplication in a similar repeat (in repeats 13 and 15, respectively) and share the same first three repeats, the same last three repeats, and an internal five repeat pattern in their repetitive domains (Fig. 7, underlined repeat units). The sequences of the SphI fragments of pthXo1, pthXo2, pthXo3 and the BamHI fragment of avrXa7-2 were deposited in GenBank under accession numbers AY495676, AY495677, AY495678, and AY495675, respectively.

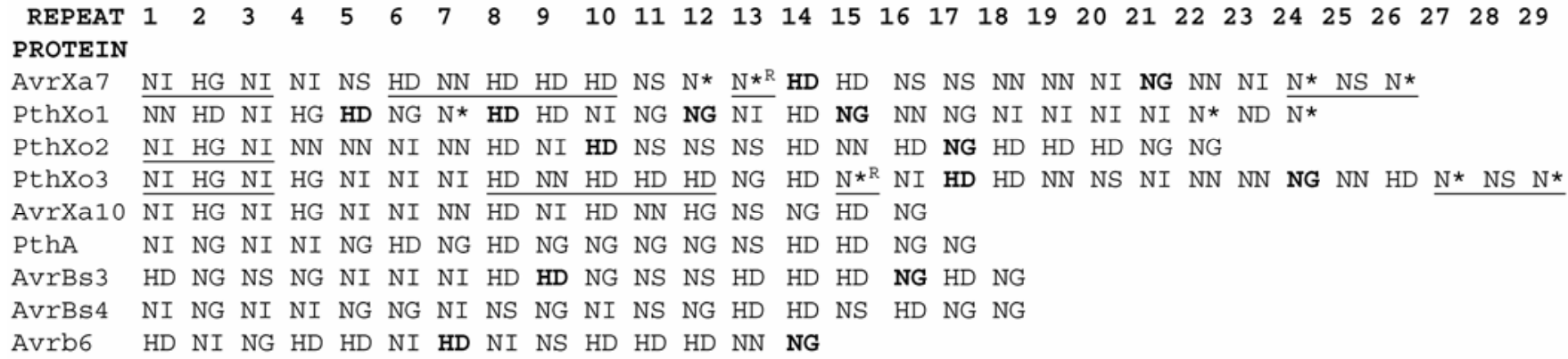

Fig. 7. Alignment of repetitive regions of selected AvrBs3/PthA proteins as represented by 12th and 13th amino acids of each repeat. The single amino acid code was used for each amino residue. An asterisk $(*)$ represents the missing 13th amino acid. $\mathrm{R}$ indicates a six-amino-acid-residue insertion in repeat (AvrXa7 and PthXo3). Similar arrangements of repeats shared between AvrXa7 and PthXo3 as identified by amino acid 12 and 13 are underlined. Boldlettered residues indicate the eight-repeat pattern in all proteins with virulence activity on rice. PthXo1 has two overlapping eight-repeat arrangements. 
AvrBs3 contains a repetitive region

with $X a 7$-dependent avirulence activity

without virulence activity.

The identification of three new distinct virulence effectors from $X$. oryzae pv. oryzae established that virulence activity could occur without $X a 7$-dependent avirulence activity and that virulence activity was provided by a variety of repeat configurations. Common among the virulence effectors was an eight-repeat pattern in which the first repeat was histidine $(\mathrm{H})$ and aspartate (D) at codons 12 and 13 and the eighth repeat had asparagines $(\mathrm{N})$ and glycine $(\mathrm{G})$ (Fig. 7, the first and eighth repeat variable residues in bold). The six repeats in between the first and eighth were variable. The same pattern occurred in the repetitive regions of AvrBs3 and Avrb6 (Fig. 7 ). To test the hypothesis that a repetitive region with this pattern could function as a virulence effector in $X$. oryzae pv. oryzae, the $0.4 \mathrm{~kb}$ of the $\mathrm{C}$-terminal coding region of avrBs 3 was replaced with the corresponding fragment of $a v r X a 7$ (discussed below). The hybrid gene, named avrBs3-7HS, was introduced into strain $\mathrm{PXO} 99^{\mathrm{A}} \mathrm{ME} 2$, and the resulting strain was tested for virulence on rice. Syringe-inoculation (data not shown) and lesion-length measurements revealed that the strain with the hybrid gene did not complement the loss of pthXo1 in PXO99 ${ }^{\mathrm{A}} \mathrm{ME} 2$ for virulence on the susceptible rice varieties IR24 (Fig. 8) and Nipponbare (data not shown). Interestingly, PXO99 ${ }^{\mathrm{A}} \mathrm{ME} 2$ with avrBs3-7HS elicited hypersensitive responses in rice carrying $X a 7$ and in pepper plants with the $B s 3$ resistance gene (Fig. 9). The results indicated that the eight-repeat pattern alone was not sufficient for virulence and, at the same time, revealed a gene with $\mathrm{Xa7}$-dependent avirulence activity without corresponding virulence activity.

\section{DISCUSSION}

\section{Involvement of avrBs3/pthA homologs}

in the pathogenicity of $X$. oryzae pv. oryzae.

Relatively few type III effector genes have been characterized from a single species or pathovar and within a single disease complex. Prior to this study, avrXa7 from the Philippine strain PXO86 was the only avrBs3/pthA gene from $X$. oryzae pv. oryzae with a major contribution to virulence. Here, four

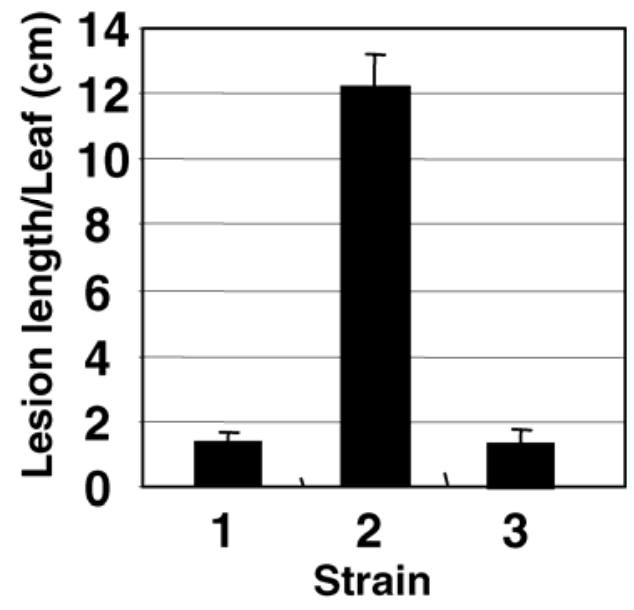

Fig. 8. Virulence activity analysis of a hybrid avrBs3-7HS in Xanthomonas oryzae pv. oryzae. The HincII/SalI fragment of avrBs3 containing the C-terminal coding region was exchanged with the corresponding fragment from $a v r X a 7$. The hybrid gene was introduced in PXO99 ${ }^{\mathrm{A}} \mathrm{ME} 2$, and the transformant was tested by leaf-clip inoculation on IR24 by needleless syringe on 14-day-old seedlings. Lane 1, PXO99A; lane 2, PXO99 ${ }^{A}$ ME2 (pHM1); and lane 3, PXO99 ${ }^{A}$ ME2 (pZWavrBs3-7HS). genes of the avrBs3/pthA gene family with virulence activity in rice, heretofore referred to as pth genes, were identified in five $X$. oryzae pv. oryzae strains. The genes, along with the original avrXa7, are considered here to be major virulence effector genes. Based on lesion-length measurements in a laboratory setting, the loss of these effectors in the different strains of $X$. oryzae pv. oryzae caused a severe loss of their ability to grow in the host. The loss was similar in degree to the reduction in growth caused by the elicitation of $\mathrm{Xa7}$-dependent resistance, and the mutant strains, other environmental factors being equal, are predicted to be at a competitive disadvantage in the natural environment to strains with a major effector gene. Six strains of $X$. oryzae pv. oryzae, including PXO86, now have been shown to have one or two major pth genes, and only one major $p$ th gene was identified in five of the strains. Mutations in four strains provided evidence that the strains were highly dependent on a single effector gene of the avrBs3/pthA gene family. Race 3 and race 9 strains from the Philippines also harbor $a v r X a 7$, and field studies suggest that $a v r X a 7$ may be an important virulence factor in these strains (Vera Cruz et al. 2000). The results of this study, therefore, support the hypothesis that many, possibly all, strains of $X$. oryzae pv. oryzae require pth genes for full virulence.

Experiments to examine in greater detail the diversity of extant pth genes in $X$. oryzae pv. oryzae populations would require genetic analyses of the type performed here on more strains. However, evidence provided here indicated that at least some of the pth genes are widespread. An allele of $a v r X a 7$ and pthXo 2 were identified as major $p t h$ genes in Korean and Japanese strains, respectively. pthXo2 was also found in PXO71. PXO71, PXO86, PXO61, and PXO99 ${ }^{\mathrm{A}}$ are strains from the Philippines representing races 1, 2, 4, and 6 of the pathogen, respectively, and also represent genetically diverse lineages as determined by restriction fragment length polymorphism analyses (Adhikari et al. 1995; Leach et al. 1992). Although from the Philippines, lineage analyses indicated PXO99A was an unusual strain and was related to strains from throughout India, Indonesia, Nepal, and Malaysia (Adhikari et al. 1995; cluster 5). The genetic relationship of $\mathrm{PXO} 99^{\mathrm{A}}$ to a large cluster of strains found throughout the rice-growing regions of Asia may
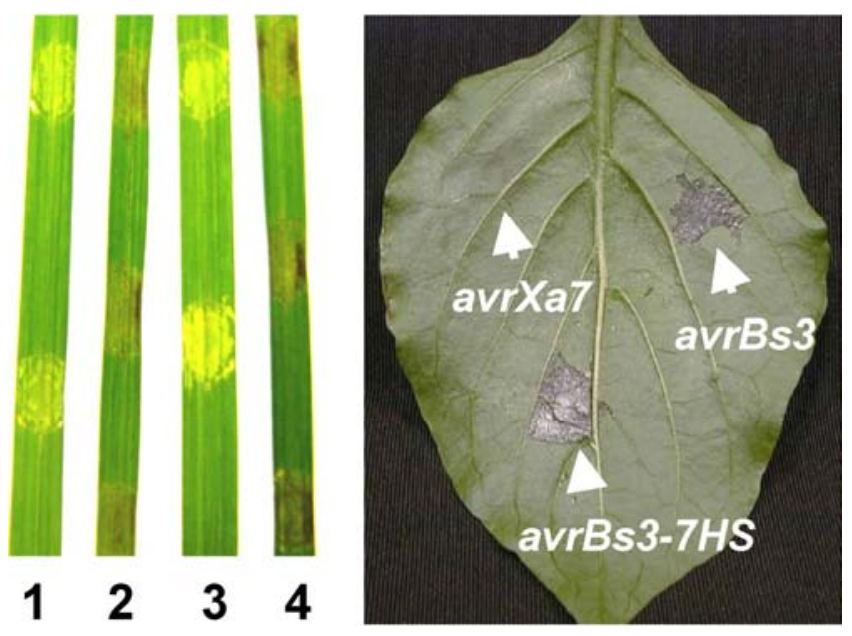

Fig. 9. Avirulence leaf assays of hybrid avrBs3-7HS in Xanthomonas oryzae pv. oryzae. A, Rice leaves inoculated with PXO99 ${ }^{\mathrm{A}} \mathrm{ME} 2$ with avrBs3 on IRBB7 (leaf 1), PXO99 ${ }^{\mathrm{A}} \mathrm{ME} 2$ with $a v r B s 3-7 H S$ on IRBB7 and IR24 (leaves 2 and 3), respectively, and PXO99 ${ }^{\mathrm{A}} \mathrm{ME2}$ with $a v r X a 7$ on IRBB7 (leaf 4). B, PXO99 ${ }^{A}$ ME2 with the genes as indicated on ECW30R(Bs3). PXO99 ${ }^{\mathrm{A}} \mathrm{ME} 2$ does not elicit a hypersensitive reaction on ECW without $B s 3$ (data not shown). 
portend that pthXol is also widely distributed (Adhikari et al. 1995). The other strains have been clustered into two large groups of strains found primarily in the Philippines (Adhikari et al. 1995; clusters 2 and 4). PXO61 contained pthXo3. A mutation was not obtained in pthXo3, and it is unknown whether pthXo3 is the only major pth gene in PXO61. Strain migration and horizontal gene transfer among lineages may be responsible for the presence of a diverse yet limited number of effectors in X. oryzae pv. oryzae. At the same time, laboratory experiments with $a v r X a 7$ provided evidence that additional novel versions can readily arise by rearrangement of the repetitive region within strains and populations (unpublished data). More $p t h$ genes seem likely to be identified in field strains of the rice pathogen in the future.

Despite the requirement for one or two major pth genes, all strains of $X$. oryzae pv. oryzae harbor multiple members of the avrBs3/pthA gene family. The presence of multiple copies may, as proposed by Yang and Gabriel (1995), facilitate the rapid generation of new pth genes in the event of host recognition or avoidance of the extant $p t h$ genes. The high gene-copy number may reflect a high degree of adaptive pressure on the pathogen populations due to the extensive cultivation and selection, either intentional or unintentional, of rice in environments highly conducive to bacterial disease. Interestingly, a relatively high number of copies of the avrBs3/pthA gene family also occurs in strains of $X$. campestris pv. malvacearum, the causal agent of bacterial blight of cotton (Yang et al. 1996). Cotton has also been an intensively managed crop for centuries, often under conditions favorable for bacterial disease. A similar situation may exist for strains of $X$. oryzae pv. oryzicola, which, if strain BLS303 is indicative of other strains, also harbor many copies of the gene family. At the same time, the other gene family members within a strain of $X$. oryzae pv. oryzae may have partial virulence activity, which here we refer to as minor virulence activity, although the term is not intended to imply the genes have no ecological consequences. Several minor genes of the avrBs3/pthA family in strain PXO86 were found to have a small effect on virulence, which could not be complemented by $a v r X a 7$ (Bai et al. 2000). Strain XcmH1005 of $X$. campestris pv. malvacearum has 10 avrBs3/pthA genes, and full water-soaking symptoms on cotton required five of the 10 genes (De Feyter et al. 1991). Thus, multiple copies of the avrBs3/pthA gene family in individual strains may serve both as a reservoir of potential recombinatorial alleles and as additional virulence effectors.

\section{Virulence effectors of the AvrBs3/PthA family \\ in $X$. oryzae pv. oryzae have diverse repetitive regions.}

The identification of new pth genes in the $X$. oryzae pv. oryzae-rice disease complex may also yield new insight into the structural requirements of the repetitive region for host specialization and $R$ gene-mediated resistance. In this regard, we classified the repeats based on the variable amino acid residues at the 12th and 13th positions of each repeat, as a convenient method to distinguish repeat units and the different members of the avrBs3/pthA gene family. There is, in fact, little evidence that the variable region specifically is critical to protein function in either avirulence or virulence. However, previous studies with $a v r B s 3$ and other gene family members have established that repeat rearrangements led to loss or changes in specificity of $R$ gene-mediated resistance and host-specific virulence activities, indicating that some feature of individual repeats are involved (Herbers et al. 1992; Yang and Gabriel 1995; Zhu et al. 1998). Three distinct pth genes in terms of the repeat organization were identified here, bringing to four the number of naturally occurring pth genes with virulence specificity for rice. Additional members of the gene family in PXO86 may provide ad- ditional virulence activities, although they are modest in comparison to the major genes $(<10 \%$ the activity of avrXa7). Only $a v r X a 7$ of the major virulence effector genes of $X$. oryzae pv. oryzae has been associated with an $R$ gene-specific resistance in rice. One common pattern among the genes with virulence activity was a HD repeat followed by a NG repeat seven repeats later. Replacement with the corresponding region from $a v r B s 3$, which has the same pattern, failed to support the idea that the pattern alone was critical for virulence activity. Serendipitously, the new hybrid gene was discovered to elicit a $X a 7$-dependent reaction in rice and a $B s 3$-dependent reaction in pepper. This gene is the first $a v r B s 3 / p t h A$ gene with no virulence activity while retaining $X a 7$-dependent recognition, and the finding showed, at least theoretically, that $\mathrm{Xa} 7$ recognition is possible in the absence of virulence activity.

\section{The potential for the general involvement of avrBs3/pthA effector genes in other bacterial disease complexes.}

The dependence of the bacterial blight disease complex of rice on members of the avrBs3/pthA gene family may be representative of other disease complexes. Evidences from studies on citrus canker disease and the causal agent $X$. axonopodis $\mathrm{pv}$. citri also indicate that the disease is highly dependent on avrBs3/pthA virulence effectors. Mutations in pthA severely reduced the disease symptoms and the ability for the bacteria to multiply in the host (Swarup et al. 1991). Genetic analysis has only been reported for a single strain, and $\mathrm{p} t h A$ is the only well-characterized $p t h$ gene from $X$. axonopodis pv. citri. Yet pthA-related genes have been detected in other strains of $X$. axonopodis pv. citri (Cubero et al. 2002; da Silva et al. 2002). Recent preliminary reports indicate that related pathogens cause similar diseases of citrus, and additional pth genes (specifically, $p t h B, p t h C$, and $p t h W$ ) have been identified (Brunings et al. 2003). Bacterial blight of cotton, also known as angular leaf spot, may also be highly dependent on the avrBs3/pthA effectors (Yang et al. 1996). Any involvement of the avrBs3/pthA genes in $X$. oryzae pv. oryzicola remains unknown, and a pth gene was not recovered from BLS303 that could compensate the loss of pthXol in strain PXO99 ${ }^{\mathrm{A}} \mathrm{ME} 2$. $A v r B s 3$, the first gene of the family to be identified, is the only pth gene with virulence activity from $X$. campestris pv. vesicatoria (Bonas et al. 1989). Therefore, mutational analyses of the avrBs3/pthA genes from other Xanthomonas strains similar to the approaches here are warranted.

\section{Implications for plant adaptation and crop improvement.}

One motivation for deciphering the mechanisms of effector function is for application to the design of better protective measures. Virulence effectors of bacterial plant pathogens are attractive targets for intervention, due to the possible fitness cost upon loss or alteration of the effector in avoidance of host recognition. Durable resistance may result if $R$ genes are selected based on recognition of conserved motifs or functions required for virulence (Lauge et al. 1998; Tai et al. 1999). Alternatively, approaches might be possible that modify the virulence-targeted pathways of the host, rendering pathogen effectors ineffective. In either case, interference in effector function may prevent or delay adaptation of virulent pathogen populations, since simple loss of the elicitor from the pathogen population may result in a concomitant reduction of virulence (Leach et al. 2001). The effectiveness of interfering with virulence effectors depends on the prevalence, plasticity, and virulence contribution of individual effectors in the population. The results of this study provided both positive and negative aspects in regard to the deployment of $X a 7$. The variety of pth genes described in this study indicates that deployment of re- 
sistance specific to any individual effector, such as $a v r X a 7$, is likely to be ineffective due to the availability of other virulence effector genes of the same type but without $\mathrm{Xa} 7$ recognition. At the same time, strains of $X$. oryzae pv. oryzae in general appear to be highly dependent on a single type of effector, and therefore, strategies targeting the $p$ th genes have potential for broad resistance of rice to bacterial blight. Alternatively, alterations of the host pathways or molecular complexes that are affected by $p t h$ gene products may provide immunity to many or all strains of the pathogen. Improved strategies should come with increased understanding of effector function and host recognition mechanisms.

\section{MATERIALS AND METHODS}

Bacterial strains, plasmids, and DNA manipulations.

Strains of Escherichia coli and X. oryzae pv. oryzae and plasmids used in this study are listed in Table 1. Standard culture and DNA techniques were used for E. coli and recombinant DNA manipulations (Ausubel et al. 1988). X. oryzae pv. oryzae was grown in either nutrient broth (Difco Laboratories, Detroit) or tryptone sucrose agar (TSA) medium (tryptone, 10 g/liter; sucrose, 10 g/liter; glutamic acid, 1 g/liter; Difco Bacto agar, $15 \mathrm{~g} / \mathrm{liter}$ ) at $28^{\circ} \mathrm{C}$. Isolates of $X$. oryzae pv. oryzae strains PXO99 ${ }^{\mathrm{A}}, \mathrm{JXO}^{\mathrm{A}}$, and $\mathrm{KXO}^{\mathrm{A}}{ }^{\mathrm{A}}$ were selected as presumed restriction modification mutants by growing on the TSA plates containing $200 \mathrm{mM}$ of 5-azacytidine (Hopkins et al. 1992). Plasmids were introduced into E. coli and X. oryzae pv. oryzae by electroporation. Antibiotics used in this study were carbenicillin, $100 \mu \mathrm{g} / \mathrm{ml}$; cephalexin, $10 \mu \mathrm{g} / \mathrm{ml}$; kanamycin, $50 \mu \mathrm{g} / \mathrm{ml}$; and spectinomycin, $100 \mu \mathrm{g} / \mathrm{ml}$.

\section{Plant materials and virulence assays.}

Rice line IR24 and near-isogenic rice line IRBB7 containing the resistance gene $X a 7$ were used for virulence and avirulence tests, respectively (Ogawa et al. 1987). Virulence assays were performed on 14- and 20-day-old rice plants by needleless syringe infiltration (Reimers et al. 1991) and leaf-clip inoculation, respectively, in growth chambers set at $28^{\circ} \mathrm{C}$ with $85 \%$ humidity for a 12-h day and 12-h night cycle (Kauffman et al. 1973). Symptoms were scored by measuring lesion lengths for clip inoculation and by observation of water-soaking after syringe infiltration, at the intervals indicated in the text. One-way analysis of variance (ANOVA) statistical analyses were performed on all measurements. The Tukey honest significant difference test was used for post-ANOVA pair-wise tests for significance, set at 5\% $(P<0.5)$. Pepper varieties ECW-30R (Bs3), a near isogenic line for the resistance gene $B s 3$ and ECW were used for avirulence assays of avrBs3 and avrBs3-7HS.

\section{Southern hybridizaton analysis.}

Standard procedures for Southern blots were utilized (Ausubel et al. 1988). Genomic DNA from X. oryzae pv. oryzae strains was digested with $S p h \mathrm{I}$ and was fractionated on a $1.25 \%$ agarose gel. Filters were probed with a ${ }^{33} \mathrm{P}$-labeled 3.1-kb SphI fragment of avrXa7. Size markers were visualized by adding labeled size markers.

\section{Transposon and marker-exchange mutagenesis.}

The central BamHI fragment of avrXa7 was cloned into pUC19. EZ::TN<KAN-2> was inserted in the repeat region of $a v r X a 7$ in pUC19, using in vitro transposition (Goryshin et al. 1998) according to the supplier (Epicentre Technologies, Madison, WI, U.S.A.), to generate pBY1. pBY1 was electroporated into $X$. oryzae pv. oryzae, and the transformed cells were plated on TSA medium containing kanamycin. Clones with resistance to kanamycin were tested on IR24 rice plants for virulence.
Genomic DNA library construction and screening.

Genomic DNA of $X$. oryzae pv. oryzae strains was partially digested with Sau3AI, and DNA fragments larger than $20 \mathrm{~kb}$ were purified from $0.8 \%$ agarose gels by electro-elution. The DNA was then ligated into BamHI-digested cosmid vector pHM1 and was packaged into lambda phages, and the phages were transduced into XL1-blue MRF' cells, according to the supplier (MaxPlax; Epicentre Technologies). Colonies were selected on Luria Bertani agar for resistance to spectinomycin. Genomic libraries had titers of about $10^{6}$ and average inserts of about $30 \mathrm{~kb}$ (data not shown). The libraries were screened using a ${ }^{32} \mathrm{P}$-labeled 3.1-kb SphI fragment of $a v r X a 7$ as a probe. Candidate clones were introduced into each respective mutant of $\mathrm{PXO}^{\mathrm{A}}{ }^{\mathrm{A}} \mathrm{JXO1}^{\mathrm{A}}$, and $\mathrm{KXO} 85^{\mathrm{A}}$ by electroporation.

\section{Complementation tests and gene characterization.}

Respective virulence mutants of $\mathrm{PXO}^{\mathrm{A}}$, JXO1 ${ }^{\mathrm{A}}$, and $\mathrm{KXO} 85^{\mathrm{A}}$ were used as the recipients of positive clones obtained from genomic libraries of $\mathrm{PXO} 99^{\mathrm{A}}, \mathrm{JXO}^{\mathrm{A}}$, and $\mathrm{KXO}^{\mathrm{A}}{ }^{\mathrm{A}}$, respectively. Transformants were inoculated on IR24 by leaf-clip inoculation and needleless syringe infiltration. Clones that restored mutant strains to virulence were further analyzed. DNA from the complementing cosmids was digested with BamHI and was analyzed by Southern hybridization. Positive BamHI fragments were extracted from gels and were subcloned into pBluescriptKS+ (Stratagene, La Jolla, CA, U.S.A.). The fragments were partially sequenced, using primers Avr1stSph-F (GCAGTGCATGCATGGCGCAATGCACTG) and AvrHincII-R (CGCCGGATCAGGGCGAGATAACTGGG). Unique genes based on the partial sequencing results were carried forward, and the $S p h \mathrm{I}$ fragments with the repetitive regions were sequenced in their entirety. The fragment ends were sequenced from both ends, using the T3 and T7 primers, and internal sequence was performed by in vitro transposition tagging and sequencing, using outwardly directed primers derived from the right and left ends of the EZ::TN $<\mathrm{KAN}-2>$. The $S p h I$ fragments of candidate $S p h I$ fragments were exchanged with the BamHI fragment of avrXa7 in pZWavrXa7 (Table 1) (Yang et al. 2000), were linearized with HindIII, and were ligated into the broad-host-range vector $\mathrm{pHM} 1$. The ligated DNA was electroporated into E. coli C2110, and the transformed cells were plated on Luria agar plates containing spectinomycin and carbenicillin. Plasmid configuration was verified by restriction enzyme analysis, and plasmids were electroporated into the respective virulence mutants. The DNA sequencing was performed at the sequencing facilities of Kansas State University.

\section{Construction of avrBs3-7HS.}

The plasmid pZWavrXa7 was digested with HincII and SalI, the latter was previously introduced immediately downstream of the second SphI site in the C-terminal of $a v r X a 7$ and $a v r B s 3$ upon addition of a FLAG epitope (Zhu et al. 1998), and the gene fragment was gel-purified. The fragment was exchanged with the HincII /SalI fragment of avrBs3 to create avrBs3-7HS

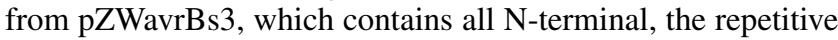
region, and 44 additional $\mathrm{C}$-terminal proximal coding sequences of $a v r B s 3$ and the approximately 400-bp HincII/SalI fragment of the $\mathrm{C}$-terminal coding region of avrXa7. The resulting plasmid was cloned in $\mathrm{pHM} 1$ and was introduced into PXO99 ${ }^{\mathrm{A}} \mathrm{ME} 2$ by electroporation.

\section{ACKNOWLEDGMENTS}

The authors thank C. Nelson for advice on statistical analyses, N. Vera Cruz for discussions regarding strain lineage, J. Leach for providing some of the strains used in this study, J. Jones for pepper varieties, and X. Tang 
and L. Claflin for reading the manuscript prior to submission. This work was supported by a competitive grant from the United States Department of Agriculture CSREES/NRI program (proposal 2000-02698) and the Kansas Agricultural Experiment Station (KAES). This is publication 04420-J of the KAES.

\section{LITERATURE CITED}

Adhikari, T. B., Vera Cruz, C. M., Zhang, Q., Nelson, R. J., Skinner, D. Z., Mew, T. W., and Leach, J. E.1995. Genetic diversity of Xanthomonas oryzae pv. oryzae in Asia. Appl. Environ. Microbiol. 61:966-971.

Ausubel, F. M., Brent, R., Kingston, R. E., Moore, D. D., Seidman, J. G., and Smith, J. A. 1988. Current Protocols in Molecular Biology. John Wiley \& Sons, New York.

Bai, J., Choi, S.-H., Ponciano, G., Leung, H., and Leach, J. E. 2000. Xanthomonas oryzae pv. oryzae avirulence genes contribute differently and specifically to pathogen aggressiveness. Mol. Plant-Microbe Interact. 13:1322-1329.

Bonas U, Stall, R. E., and Staskawicz, B. 1989. Genetic and structural characterization of the avirulence gene avrBs3 from Xanthomonas campestris pv. vesicatoria. Mol Gen Genet. 218:127-36.

Brunings, A. M., and Gabriel, D. W.2003. Xanthomonas citri: Breaking the surface. Mol. Plant Pathol. 4:141-157.

Buttner, D., and Bonas, U. 2002. Getting across bacterial type III effector proteins on their way to the plant cell. EMBO (Eur. Mol. Biol. Organ.) J. 21:5313-5322.

Chang, J. H., Goel, A.K., Grant, S. R., Dangl. J. L. 2004. Wake of the flood: Ascribing functions to the wave of type III effector proteins of phytopathogenic bacteria. Curr. Opin. Microbiol. 7:11-18.

Cubero, J., and Graham, J. H. 2002. Genetic relationship among worldwide strains of Xanthomonas causing canker in citrus species and design of new primers for their identification by PCR. Appl. Environ. Microbiol. 68:1257-1264.

da Silva, A. C., Ferro, J. A., Reinach, F. C., Farah, C. S., Furlan, L. R., Quaggio, R. B., Monteiro-Vitorello, C. B., Van Sluys, M. A., Almeida, N. F., Alves, L. M., do Amaral, A. M., Bertolini, M. C., Camargo, L. E., Camarotte, G., Cannavan, F., Cardozo, J., Chambergo, F., Ciapina, L. P., Cicarelli, R. M., Coutinho, L. L., Cursino-Santos, J. R., El Dorry, H. Faria, J. B., Ferreira, A. J., Ferreira, R. C., Ferro, M. I., Formighieri, E. F., Franco, M. C., Greggio, C. C., Gruber, A., Katsuyama, A. M., Kishi, L. T., Leite, R. P., Lemos, E. G., Lemos, M. V., Locali, E. C., Machado, M. A., Madeira, A. M., Martinez-Rossi, N. M., Martins, E. C., Meidanis, J., Menck, C. F., Miyaki, C. Y., Moon, D. H., Moreira, L. M., Novo, M. T., Okura, V. K., Oliveira, M. C., Oliveira, V. R., Pereira, H. A., Rossi, A., Sena, J. A., Silva, C., de Souza, R. F., Spinola, L. A., Takita, M. A., Tamura, R. E., Teixeira, E. C., Tezza, R. I., Trindade dos, S. M., Truffi, D., Tsai, S. M., White, F. F., Setubal, J. C., and Kitajima, J. P. 2002. Comparison of the genomes of two Xanthomonas pathogens with differing host specificities. Nature 417:459-463.

De Feyter, R., and Gabriel, D. W. 1991. At least six avirulence genes are clustered on a 90-kilobase plasmid in Xanthomonas campestris pv. malvacearum. Mol. Plant-Microbe Interact. 4:423-432.

Deng, W. L., Rehm, A. H., Charkowski, A. O., Rojas, C. M., and Collmer, A. 2003. Pseudomonas syringae exchangeable effector loci: Sequence diversity in representative pathovars and virulence function in $P$. syringae pv. syringae B728a. J. Bacteriol. 185:2592-2602.

Gassmann W., Dahlbeck, D., Chesnokova, O., Minsavage, G.V., Jones, J. B., and Staskawicz, B. J. 2000. Molecular evolution of virulence in natural field strains of Xanthomonas campestris pv. vesicatoria. J. Bacteriol. 182:7053-7059.

Goryshin, I. Y., and Reznikoff, W. S. 1998. Tn5 in vitro transposition. J. Biol. Chem. 273:7367-7374.

Guttman, D. S., Vinatzer, B. A., Sarkar, S. F., Ranall, M. V., Kettler, G., and Greenberg, J. T. 2002. A functional screen for the type III (Hrp) secretome of the plant pathogen Pseudomonas syringae. Science 295:1722-1726.

Herbers, K., Conrads-Strauch, J., and Bonas, U. 1992. Race-specificity of plant resistance to bacterial spot disease determined by repetitive motifs in a bacterial avirulence protein. Nature 356:172-174.

Hopkins, C. M., White, F. F., Choi, S. H., Guo, A., and Leach, J. E. 1992 Identification of a family of avirulence genes from Xanthomonas oryzae pv. oryzae. Mol. Plant-Microbe Interact. 5:451-459.
Kauffman, H. E., Reddy, A. P. K., Hsiek, S. P. V., and Marca, S. D. 1973. An improved technique for evaluating resistance of race varieties to Xanthomonas oryzae. Plant Dis. Rep. 57:537-541.

Kearney B, and Staskawicz, B. J. 1990. Widespread distribution and fitness contribution of Xanthomonas campestris avirulence gene avrBs 2 . Nature. 346:385-386.

Lauge, R., Joosten, M. H., Haanstra, J. P., Goodwin, P. H., Lindhout, P., and De Wit, P. J. 1998. Successful search for a resistance gene in tomato targeted against a virulence factor of a fungal pathogen. Proc. Natl. Acad. Sci. U.S.A. 95:9014-9018.

Leach, J. E., Rhoads, M. L., Vera Cruz, C. M., White, F. F., Mew, T. W., and Leung, H., 1992. Assessment of genetic diversity and population structure of Xanthomonas oryzae pv. oryzae with a repetitive DNA element. Appl. Environ. Microbiol. 58:2188-2195.

Leach, J. E., Vera-Cruz, C. M., Bai, J. F., and Leung, H., 2001. Pathogen fitness penalty as a predictor of durability of disease resistance genes. Annu. Rev. Phytopathol. 39:187-224.

Leong, S. A., Ditta, G. S., and Helinski, D. R. 1982. Heme biosynthesis in Rhizobium. J. Biol. Chem. 257:8724-8730.

Ogawa, T., and Yamamoto, T. 1987. Selection of recurrent parents to develop near-isogenic lines resistant to bacterial leaf blight of rice. Jpn. Agri. Res. 21:65-69.

Reimers, P. J., and Leach, J. E. 1991. Race-specific resistance to Xanthomonas oryzae pv. oryzae conferred by bacterial blight resistance gene $\mathrm{Xa-10}$ in rice (Oryzae sativa) involves accumulation of a lignin-like substance in host tissues. Physiol. Mol. Plant Pathol. 38:39-55.

Salanoubat, M., Genin, S., Artiguenave, F., Gouzy, J., Mangenot, S., Arlat, M., Billault, A., Brottier, P., Camus, J. C., Cattolico, L., Chandler, M., Choisne, N., Claudel-Renard, C., Cunnac, S., Demange, N., Gaspin, C., Lavie, M., Moisan, A., Robert, C., Saurin, W., Schiex, T., Siguier, P., Thebault, P., Whalen, M., Wincker, P., Levy, M., Weissenbach, J., and Boucher, C. A. 2002. Genome sequence of the plant pathogen Ralstonia solanacearum. Nature 415:497-502.

Staskawicz, B. J., Mudgett, M. B., Dangl, J., and Galan, J. E. 2001. Common and contrasting themes of plant and animal diseases. Science 292:2285-2289.

Swarup, S., De Feyter, R., Brlansky, R. H., and Gabriel, D. W. 1991. A pathogenicity locus from Xanthomonas citri enables strains from several pathovars of $X$. campestris to elicit canker-like lesions on citrus. Phytopathology 81:802-809.

Tai, T. H., Dahlbeck, D., Clark, E. T., Gajiwala, P., Pasion, R., Whalen, M. C., Stall, R. E., and Staskawicz, B. J. 1999. Expression of the Bs2 pepper gene confers resistance to bacterial spot disease in tomato. Proc. Natl. Acad. Sci. U.S.A. 96:14153-14158.

Vera Cruz, C. M., Bai, J., Ona, I., Leung, H., Nelson, R. J., Mew, T. W., and Leach, J. E. 2000. Predicting durability of a disease resistance gene based on an assessment of the fitness loss and epidemiological consequences of avirulence gene mutation. Proc. Natl. Acad. Sci. U.S.A. 97:13500-13505

White, F. F., Yang, B., and Johnson, L. B. 2000. Prospects for understanding avirulence gene function. Curr. Opin. Plant Biol. 3:291-298.

Yang, B., Zhu, W., Johnson, L. B., and White, F. F. 2000. The virulence factor AvrXa7 of Xanthomonas oryzae pv. oryzae is a type III secretion pathway-dependent, nuclear-localized, double-stranded DNA binding protein. Proc. Natl. Acad. Sci. U.S.A. 97:9807-9812.

Yang, Y., De Feyter, R., and Gabriel, D. W. 1994. Host-specific symptoms and increased release of Xanthomonas citri and X. campestris pv. malvacearum from leaves are determined by the 102-bp tandem repeats of pthA and $a v r b 6$, respectively. Mol. Plant-Microbe Interact. 7:345-355.

Yang, Y., and Gabriel, D. W. 1995. Intragenic recombination of a single plant pathogen gene provides a mechanism for the evolution of new host specificities. J. Bacteriol. 177:4963-4968.

Yang, Y., Yuan, Q., and Gabriel, D. W. 1996. Watersoaking function(s) of $\mathrm{XcmH} 1005$ are redundantly encoded by members of the Xanthomonas avr/pth gene family. Mol. Plant-Microbe Interact. 9:105-113.

Yanisch-Perron, C., Vieira, J., and Messing, J. 1985. Improved M13 phage cloning vectors and host strains: Nucleotide sequences of the M13mp18 and pUC19 vectors. Gene 33:103-119.

Zhu, W., Yang, B., Chittoor, J. M., Johnson, L. B., and White, F. F. 1998 AvrXA10 contains an acidic transcriptional activation domain in the functionally conserved $\mathrm{C}$ terminus. Mol. Plant-Microbe Interact. 11:824-832. 